\title{
PENERAPAN MODEL INKUIRI TERBIMBING DALAM MENINGKATKAN PEMAHAMAN KONSEP SISWA PADA MATA PELAJARAN IPS
}

\author{
Firman Yudhanegara $^{1}$, Sigit Vebrianto Susilo ${ }^{2}$, Suningrat ${ }^{3}$ \\ ${ }^{1}$ Program Studi PG PIAUD FAI Universitas Majalengka, \\ ${ }^{2}$ Program Studi PGSD FKIP Universitas Majalengka, \\ ${ }^{1}$ Program Studi PGSD FKIP Universitas Majalengka, \\ ${ }^{1}$ firmanyudhanegara@yahoo.com, ${ }^{2}$ sigit.vebrianto@gmail.com
}

\begin{abstract}
Abstrak
Penelitian ini dilatarbelakangi oleh permasalahan terhadap rendahnya pemahaman konsep siswa pada mata pelajaran IPS di SD Negeri Sumber Kulon I, salah satu penyebabnya yaitu kurang variatifnya guru dalam menerapkan model pembelajaran sehingga mengakibatkan pemahaman konsep siswa rendah. Penelitian ini dilakukan untuk meningkatkan pemahaman konsep siswa pada mata pelajaran IPS di kelas V SD Negeri Sumber Kulon I. Penelitian ini merupakan penelitian tindakan kelas yang dilakukan oleh guru dan peneliti, tindakan penelitian dilakukan dalam dua siklus. Subjek penelitian ini adalah siswa kelas V SD Negeri Sumber Kulon I dengan jumlah siswa 22 orang terdiri dari 12 siswa laki-laki dan 13 orang siswa perempuan. Alat pengumpulan data yang digunakan peneliti adalah beruapa butir soal, observasi yang berupa lembar observasi kinerja guru dan lembar observasi kegiatan siswa serta dokumentasi. Data yang berupa hasil tes sebagai data primer, hasil observasi dan dokumentasi sebagai data pendukung. Berdasarkan hasil penelitian dapat disimpulkan bahwa dengan menerapkan model inkuiri terbimbing dapat meningkatkan pemahaman konsep pada mata pelajaran IPS. Peningkatan tersebut dibuktikan dengan pencapaian KKM pada siklus 1, pencapaian KKM 65\%. Demikian pula setelah dilakukan perbaikan pada tindakan siklus 2, pencapaian KKM meningkat menjadi77\%. Proses pembelajaran IPS sesuai dengan hasil observasi, pada siklus 1 siswa sudah mulai menunjukkan keaktifannya walaupun masih bingung dengan penerapan metode inkuiri terbimbing. Pada siklus 2 sebagian besar siswa aktif dalam proses pembelajaran.
\end{abstract}

Kata Kunci: Pemahaman Konsep Siswa, Model Pembelajaran Inkuiri Terbimbing 


\section{Pendahuluan}

Pendidikan memegang peranan yang penting di setiap negara karena pendidikan akan menjamin kelangsungan hidup satu bangsa dan negara. Seiring dengan perkembangan zaman, pendidikan harus didesain yang konkrit dan riil untuk mempersiapkan generasi bukan bertahan hidup dalam era globalisasi tetapi juga untuk menguasai globalisasi. Dinamika pendidikan ditandai oleh suatu pembaharuan dan tranformasi pemikiran mengenai hakikat pembelajaran itu sendiri yaitu mewujudkan pembelajaran sebagai suatu proses yang aktif. Terdapat implikasi salah satunya yaitu pendidik harus melibatkan.

Kegiatan komunikasi sangat diperlukan maka tentu akan dibutuhkan adanya alat komunikasi yang berperan sebagai media berikut pesan. Mata pelajaran yang harus dikembangkan dalam proses perkembangan siswa salah satunya adalah Ilmu Pengetahuan Sosial (IPS). Ilmu Pengetahuan Sosial (IPS) adalah ilmu yang mempelajari manusia dalam segala aspek hidupnya, ciri khasnya, tingkah lakunya, baik perseorangan maupun bersama, dalam lingkup kecil maupun besar, serta interaksi dalam lingkungan hidupnya. Objek material dalam IPS adalah berupa tingkah laku dalam tindakan yang khas manusia, bebas dan tidak deterministik. Menurut Sapriya (Mulyana 2014), menyatakan bahwa "Program Pendidikan IPS yang komprehensif adalah program yang mencangkup empat dimensi meliputi: (1) dimensi pengetahuan (knowledge); (2) dimensi keterampilan (skills); dimensi nilai dan sikap (values and attitudes); (4) dimensi tindakan (action)". Pembelajaran IPS yang bermutu menuntut peserta didik menguasai seluruh konsep secara interdisipliner dan transdisipliner keilmuan terpadu dengan masalah sosial budaya dan unsur keguruan untuk kepentingan pembelajaran peserta didik.
Mengetahui dan menyadari apa yang dipelajari dalam pembelajaran IPS sangatlah penting, sehingga belajar istilahistilah atau konsep-konsep dalam IPS perlu didukung oleh pemahaman terhadap makna istilah dan makna konsep-konsep tersebut. Hal ini untuk menghindari terjadinya verbalisme pada diri peserta didik. Oleh karena itu, dalam pembelajaran IPS untuk mengetahui dan memahami suatu istilah dan konsep diharapkan peserta didik memiliki kemampuan menerapkan pengembangan keterampilan pemahaman.

Pemahaman merupakan hasil proses belajar mengajar yang mempunyai indikator individu dapat menjelaskan atau mendefinisikan suatu unit informasi dengan kata-kata sendiri. Berdasarkan pernyataan tersebut, peserta didik dituntut tidak sebatas mengingat kembali pelajaran, namun lebih dari itu peserta didik mampu mendefinisikan. Hal ini menunjukan peserta didik telah memahami pelajaran walau dalam bentuk susunan kalimat berbeda tapi kandungan makna tidak berubah. Hal tersebut sejalan dengan yang dikemukakan oleh Carin dan Sund (Susanto: 2013) pemahaman bukan sekedar mengetahui, yang biasanya hanya sebatas mengingat kembali pengalaman dan memproduksi apa yang pernah dipelajari. Bagi orang yang benar-benar paham ia akan mampu memberikan gambaran, contoh dan penjelasan yang lebih luas dan memadai.

Berdasarkan observasi yang telah dilakukan, perlunya upaya peningkatan kualitas pembelajaran di sekolah. Salah satu upaya memperbaiki kualitas belajar Peserta Didik di dalam kelas adalah orientasi pembelajaran yang semula berpusat pada guru (teacher-centered) beralih berpusat pada murid (studentcentered). Solusi yang dapat dilakukan untuk mengatasi masalah tersebut adalah dengan menerapkan model pembelajaran yang disesuaikan dengan konsep yang lebih tepat dengan kondisi yang ada di kelas, dan dipadukan dengan metode pembelajaran yang lain untuk memperbaiki pemahaman peserta didik. Sehingga, dalam memilih suatu model pembelajaran guru harus memiliki pertimbangan-pertimbangan seperti materi pelajaran, jam pelajaran, tingkat 
perkembangan kognitif peserta didik, lingkungan belajar, dan fasilitas penunjang yang tersedia, sehingga tujuan pembelajaran yang telah ditetapkan dapat tercapai. Salah satu model pembelajaran yang memberikan dampak positif bagi pemahaman peserta didik dalam proses pembelajaran adalah model pembelajaran inkuiri terbimbing. Menurut Sanjaya (2006:200) pembelajaran inkuiri terbimbing yaitu suatu model pembelajaran inkuiri yang dalam pelaksanaanya guru menyediakan bimbingan atau petunjuk cukup luas kepada siswa. Sebagian perencanaannya dibuat oleh guru, siswa tidak merumuskan problem atau masalah. Dalam pembelajaran inkuiri terbimbing guru tidak melepas begitu saja kegiatankegiatan yang dilakukan oleh siswa. Guru harus memberikan pengarahan dan bimbingan kepada siswa dalam melakukan kegiatan-kegiatan sehingga siswa yang berpikir lambat atau siswa yang mempunyai intelegensi rendah tetap mampu mengikuti kegiatan-kegiatan yang sedang dilaksanakan. Model inkuiri terbimbing adalah model pembelajaran yang dipergunakan oleh guru yang melibatkan siswa dalam pembelajaran melalui kegiatan penelitian yang bertujuan untuk menemukan informasi dengan bantuan guru. Pembelajran inkuiri terbimbing diterapkan agar para siswa bebas mengembangkan konsep yang mereka pelajari. Siswa diberi kesempatan untuk memecahkan masalah yang mereka hadapi secara individu atau berkelompok, di dalam kelas mereka diajarkan berinteraksi sosial dengan kawan sebayanya untuk saling bertukar informasi antar kelompok.

\section{A. Model Pembelajan Inkuiri Terbimbing}

Salah satu model pembelajaran yang mampu membuat siswa untuk berpikir secara aktif dan bekerja ilmiah di dalam proses pembelajaran adalah metode pembelajaran inkuiri. Model pembelajaran inkuiri tidak hanya mengembangkan kemampuan intelektual tetapi seluruh potensi yang ada, termasuk pengembangan emosional dan pengembangan keterampilan. Dalam model pembelajaran inkuiri ini, siswa dihadapkan pada sebuah masalah yang tidak sengaja dibuat oleh guru atau hasil "rekayasa", sehingga siswa harus mengerahkan seluruh pikiran dan keterampilannya untuk mendapatkan temuantemuan di dalam masalah itu melalui poses penelitian.

Savage dan Armstrong (Sapriya, 2009: 80) telah mengembangkan model inkuiri sebagai salah satu bagian dari upaya guru dalam membantu para siswa sekolah dasar dalam meningkatkan kemampuan berpikir. Pendekatan pembelajaran inkuiri ini biasa disebut juga pendekatan penemuan yang artinya penyajian pelajaran yang memberikan kesempatan kepada siswa atau siswa untuk menemukan informasi dengan atau tanpa bantuan guru (Rahayu : 2014). Sedangkan Wina Sanjaya (2006: 194) menyatakan bahwa inkuiri merupakan rangkaian kegiatan pembelajaran yang menekankan pada proses berpikir secara kritis dan analitis untuk mencari dan menemukansendiri jawaban dari suatu masalah yang dipertanyakan. Kesimpulan dari pendapat di atas, bahwa model inkuiri adalah model pembelajaran yang dipergunakan oleh guru yang melibatkan siswa dalam pembelajaran melalui kegiatan penelitian yang bertujuan untuk menemukan materi pembelajaran tertentu.

Model inkuiri terbagi menjadi tiga jenis salah satunya yaitu inkuiri terbimbing (guided inquiry)merupakan salah satu model pengajaran yang dirancang untuk mengajarkan konsep-konsep dan hubungan antar konsep. Ketika menggunakan model pembelajaran ini, guru menyajikan contohcontoh tersebut, dan memberikan semacam penutup ketika siswa telah mampu mendeskripsikan gagasan yang diajarkan oleh guru. Suryosubroto (Gumay: 2014) mengemukakan bahwa inkuiri memiliki keunggulan yaitu : (1) membantu siswa mengembangkan atau memperbanyak persediaan dan penguasaan keterampilan dan proses kognitif siswa, (2) Pengetahuan yang diperoleh bersifat sangat kukuh; dalam arti pendalaman dari pengertian; 
referensi, dan transfer, (3) membangkitkan gairah pada siswa, (4) memberi kesempatan pada siswa untuk bergerak maju sesuai dengan kemampuannya sendiri menyebabkan siswa mengarahkan sendiri cara belajarnya, sehingga ia lebih merasa terlibat dan bermotivasi sendiri untuk belajar, (6) membantu memperkuat pribadi siswa dengan bertambahnya kepercayaan diri siswa, (7) metode ini berpusat pada siswa sehingga guru hanya menjadi teman belajar.

Adapun kekurangan atau kelemahan metode inkuiri menurut wina sanjaya (2006: 206-207) yaitu:

a. Sulit mengontrol kegiatan dan keberhasilan siswa.

b. Sulit merencanakan pembelajaran, karena terbentur dengan kebiasaan siswa dalam belajar.

c. Memerlukan waktu yang panjang, sehingga guru sulit menyesuaikannya dengan waktu yang telah ditentukan.

d. Sulit diimplementasikan oleh setiap guru, karena kriteria keberhasilan belajar ditentukan oleh kemampuan siswa menguasai materi pelajaran.

Kelemahan yang ada pada metode inkuiri dapat menjadi masukan bagi guru dalam proses pembelajaran. Kelemahankelemahan tersebut dapat diminimalisir dengan upaya guru lebih kreatif dalam mengemas suatupembelajaran, sehingga pembelajaran terasa menarik dan menyenangkan. Jika siswa merasa tertarik terhadap suatu pembelajaran tentu dapat lebih bersemangat dalam belajar sehingga dapat meraih nilai yang baik.

Pada hakekatnya inkuiri merupakan suatu proses. Proses ini bermula dari merumuskan masalah, merumuskan hipotesis, mengumpulkan bukti, menguji hipotesis, dan menarik kesimpulan sementara W. Gulo (Rahayu : 2014) Proses inkuiri dapat digambarkan dalam gambar di bawah ini.

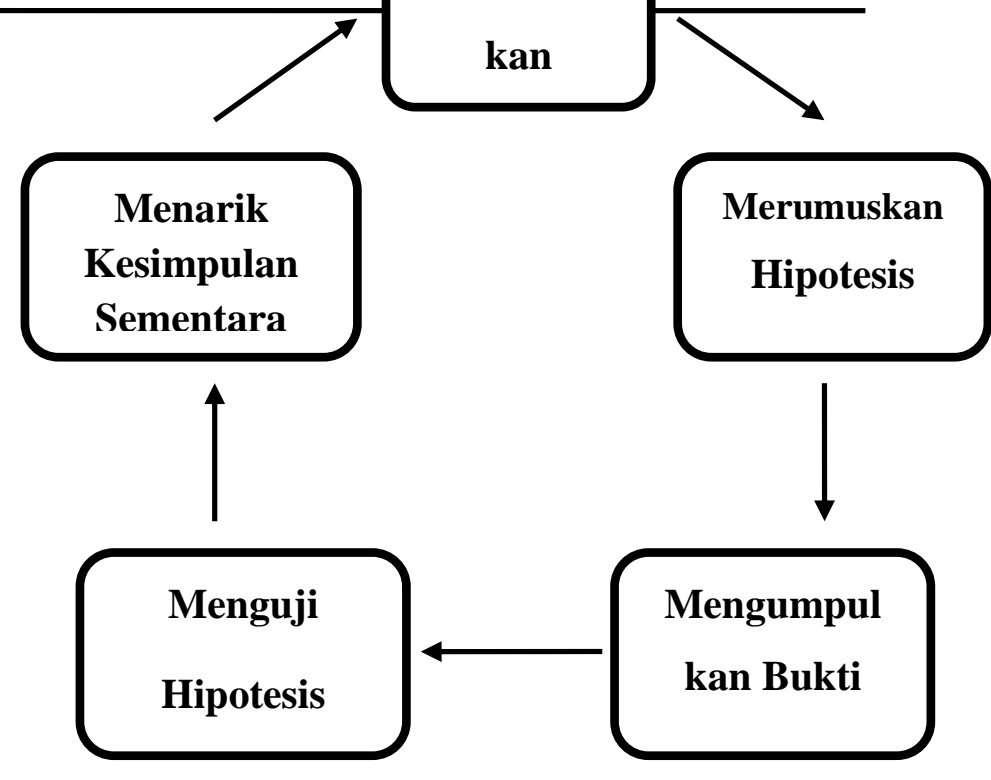

Gambar 1 Proses Inkuiri

Semua tahap dalam proses inkuiri di atas merupakan kegiatan belajar dari siswa. Guru berperan untuk mengoptimalkan kegiatan tersebutpada proses belajar mengajar sebagai fasilitator, nara sumber, dan penyuluh kelompok atau pengarah. Para siswa didorong untuk mencari pengetahuan sendiri, bukan dijejali dengan pengetahuan.

Kegiatan belajar mengajar dimulai dengan guru mengajukan pertanyaan, anjuran membaca buku, atau aktivitas belajar lainnya yang mengarah pada persiapan pemecahan masalah, kemudian siswa diberi kesempatan untuk mengidentifikasi sebanyak mungkin agenda-agenda masalah yang relevan dengan materi pelajaran. Dari agendaagenda masalah yang ada dipilih salah satu dan dirumuskan dalam bentuk hipotesis sebagai jawaban sementara.

\section{B. Pemahaman Konsep}

Bloom (Waluya: 2014 ) menyatakan bahwa pemahaman konsep adalah kemampuan untuk menyerap arti dari materi atau bahan yang dipelajarai pemahaman menurut Bloom ini adalah seberapa besar siswa mampu menerima, menyerap, dan memahami serta memahami 
pelajaran yang diberikan oleh guru kepada siswa, atau sejauh mana siswa dapat memahami serta mengerti apa yang ia baca, yang dilihat, yang dialami, atau yang ia rasakan berupa hasil penelitian atau observasi langsung yang ia lakukan.

Menurut Carin dan Sund (Susanto : $2013: 7$ ), pemahaman dapat dikategorikan kepada beberapa aspek, dengan kriteria-kriteria sebagai berikut :

1) Pemahaman merupakan kemampuan untuk menerangkan dan menginterpretasikan sesuatu ;

2) Pemahaman bukan sekedar mengetahui;

3) Pemahaman lebih dari sekedar mengetahui;

4) Pemahaman merupakan suatu proses bertahap yang masingmasing tahap mempunyai kemampuan tersendiri;

Berdasarkan kriteria pemahaman diatas bahwa pemahaman merupakan kemampuan untuk menerangkan dan menginterpretasikan sesuatu ini berarti bahwa seseorang yang telah memahami sesuatu atau telah memperoleh pemahaman akan mampu menerangkan atau menjelaskan kembali apa yang telah ia terima. Selain itu, bagi mereka yang telah memahami tersebut, maka ia mampu memberikan interpretasi atau menafsirkan secara luas sesuai dengan keadaan yang ada disekitarnya, ia mampu menghubungkan dengan kondisi yang ada saat ini dan yang akan datang. Selain itu pemahaman bukan sekedar mengetahui yang biasanya hanya sebatas mengingat kembali pengalaman dan memproduksi apa yang pernah dipelajari. Bagi orang yang benar-benar telah paham ia akan mampu memberikan gambaran, contoh, dan penjelasan yang lebih luas dan memadai. Pemahaman lebih dari sekedar mengetahui karena pemahaman melibatkan proses mental yang dinamis; dengan memahami ia akan mampu memberikan uraian dan penjelasan yang lebih kreatif, tidak hanya memberikan gambaran dalam satu contoh saja tetapi mampu memberikan gambaran yang luas dan baru sesuai dengan kondisi saat ini. Pemahaman merupakan suatu proses bertahap yang masing-masing tahap mempunyai kemampuan tersendiri seperti menerjemahkan, menginterpretasikan, ekstrapolasi, aplikasi, analisis, sintesis, dan evaluasi.

Berdasarkan pendapat di atas, dapat disimpulkan bahwa pemahaman adalah kemampuan seseorang untuk mengerti atau memahami sesuatu setelah sesuatu itu diketahui dan diingat, memahami atau mengerti apa yang diajarkan, mengetahui apa yang sedang dikomunikasikan serta dapat menjelaskan pengetahuan yang telah diketahui dengan kata-kata sendiri. Dengan kata lain, memahami adalah mengerti tentang sesuatu dan dapat melihatnya dari berbagai segi. Seorang peserta didik dikatakan memahami sesuatu apabila ia dapat memberikan penjelasan atau memberi uraian yang lebih rinci tentang hal itu

Rosser (Waluya : 2014 ) konsep adalah suatu abstraksi yang mewakili satu kelas objek-objek, kejadian-kejadian, kegiatan-kegiatan, atau hubunganhubungan yang mempunyai atribut-atribut yang sama. Konsep adalah ide abstrak yang memungkinkan kita dapat mengelompokan benda-benda, simbol-simbol, atau peristiwa tentu ke dalam contoh dari ide abstrak tersebut itu. Dahar (Waluya : 2014) berpendapat bahwa konsep merupakan penyajian-penyajian internal dari sekelompok stimulus. Konsep-konsep tidak dapat diamati, konsep-konsep harus disimpulkan dari perilaku. Konsep merupakan dasar bagi proses mental yang lebih tinggi untuk merumuskan generalisasi. Dengan demikian konsep merupakan buah pemikiran seseorang atau sekelompok 
orang yang dinyatakan dalam definisi sehingga melahirkan produk pengetahuan meliputi prinsip, hukum, dan teori. Konsep diperoleh dari fakta, peristiwa, pengalaman, melalui generalisasi dan berpikir abstrak.

Pemahaman suatu konsep dengan baik sangatlah penting bagi siswa karena dalam memecahkan masalah siswa harus mengetahui aturan-aturan yang relevan dan aturan- aturan ini didasarkan pada konsepkonsep yang diperolehnya. Siswa dikatakan telah memahami suatu konsepjika siswa dapat menjelaskan suatu informasi dengan kata-katanya sendiri. Dalam hal ini siswa dituntut tidak hanya sebatas menginggat sesuatu bahan pelajaran tetapi juga mampu menjekaskan kembali informasi yang diperoleh dengan menggunakan katakatanya sendiri meskipun penjelasan tersebut susunan kata-katanya tidak sesuai sama dengan apa yang diberikan kepada siswa akan tetapi kandungan maknanya tetap sama.

Agar dapat memahami suatu konsep, siswa harus membentuk konsep sesuai dengan stimulus yang diterimanya dari lingkungan atau sesuai dengan pengalaman yang diperoleh dalam perjalanan hidupnya. Pengalaman- pengalaman yang harus dilalui oleh siswa merupakan serangkaian kegiatan pembelajaran yang dapat menunjang terbentuknya konsep-konsep tersebut. Karena itu, guru harus bisa menyusun pembelajaran yang didalamnya berisi kegiatan-kegiatan belajar siswa yang sesuai dengan konsep-konsep yang akan dibentuknya.

Berdasarkan pendapat diatas dapat disimpulkan bahwa konsep merupakan abstraksi kesamaan atau keterhubungan dari sekelompok benda atau sifat, kesamaan yang dimaksud adalah adanya unsur-unsur yang sama baik dalam bentuk konkrit maupun dalam bentuk abstrak. Konsep dapat dinyatakan dalam sejumlah bentuk konkrit atau abstrak, luas atau sempit, satu kata frase.

Pemahaman konsep sangat penting, karena dengan penguasaan konsep akan memudahkan siswa dalam mempelajari IPS. Pada setiap pembelajaran diusahakan lebih ditekankan pada penguasaan konsep agar siswa memiliki bekal dasar yang baik untuk mencapai kemampuan dasar yang lain seperti penalaran, komunikasi, koneksi dan pemecahan masalah. Terkait pemahaman konsep (Sanjaya, 2009: 70) mengemukakan bahwa pemahaman konsep adalah kemampuan peserta didik yang berupa penguasaan sejumlah materi pelajaran, tetapi mampu mengungkapkan kembali dalam bentuk lain yang mudah dimengerti, memberikan interpretasi data dan mampu mengaplikasi konsep yang sesuai dengan struktur kognitif yang dimilikinya.

Berdasarkan pengertian diatas dapat disimpulkan bahwa, pemahaman konsep adalah kemampuan menangkap pengertian-pengertian seperti mampu memahami atau mengerti apa yang diajarkan, mengerti apa yang sedang dikomunikasikan, memberikan penjelasan atau memberi uraian yang lebih rinci dengan menggunakan kata-kata sendiri, mampu menyatakan ulang suatu konsep, mampu mengklasifikasikan suatu objek dan mampu mengungkapkan suatu objek dan mampu mengungkapkan suatu materi yang disajikan kedalam bentuk yang lebih dipahami. Anderson dan Krathwohl (Irwandani 2015) membagi 7 (tujuh) proses-proses kognitif dalam aspek memahami meliputi menafsirkan, mencontohkan, mengklasifikasikan, merangkum, menarik inferensi, membandingkan dan menjelaskan.

\section{Metode Penelitian}

Metode yang digunakan dalam penelitian ini adalah metode penelitian 
tindakan kelas. Penelitian tindakan kelas ini dilakukan dengan harapan dapat memperbaiki kualitas pendidikan secara langsung yang melibatkan masalah yang timbul dilapangan. Khususnya masalah yang ada di dalam kelas. PTK adalah sebuah bentuk kegiatan refleksi diri yang dilakukan oleh para pelaku pendidikan dalam situasi kependidikan untuk memperbaiki rasionalitas dan keadilan (Kunandar, 2009: 46). Sedangkan menurut Rapoport (dalam Kunandar, 2009: 46) PTK adalah penelitian untuk membantu seseorang dalam mengatasi secara praktis persoalan yang diharapkan dalam situasi darurat dan membantu pencapaian tujuan. PTK memiliki peran yang penting dalam meningkatkan mutu atau kualitas pembelajaran apabila dilakukan dengan baik dan benar.

Prosedur penelitian ini didahului dengan observasi awal. Observasi awal tersebut dilaksanakan dengan tujuan untuk mencari dan mengumpulkan informasi kondisi awal di kelas saat proses pembelajaran berlangsung dan mengamati permasalahan-permasalahan yang sering muncul dalam proses pembelajaran. Pelaksanaan penelitian tindakan kelas ini dilaksanakan sesuai dengan prosedur PTK, Penelitian ini menggunakan model Kemmis $\mathrm{M}$. Taggart yang berbentuk 2 siklus. Namun jika dalam 2 siklus belum terjadi peningkatan pemahaman siswa mengenai konsep IPS tersebut maka penelitian dilanjutkan ke siklus 3. Setiap siklusnya terdiri dari empat tahapan yaitu perencanaan tindakan (planning), pelaksanaan tindakan (acting), observasi (observing), dan refleksi (reflecting).

Subjek dalam penelitian tindakan kelas (PTK) adalah siswa kelas V SD Negri Sumber Kulon I. Dengan jumlah siswa 22 orang terdiri dari 12 siswa laki-laki dan 10 siswa perempuan. Teknik pengumpulan data merupakan langkah paling utama dalam penelitian, karena salah satu tujuan dari penelitian adalah mendapatkan data. Pengumpulan data dapat dilakukan dalam berbagai cara, berbagai seting dan berbagai sumber. Pada penelitian ini, pengumpulan data dilakukan pada natural seting ( kondisi yang alamiah), sumber data primer, dan teknik pengumpulan data lebih banyak pada observasi, wawancara, dan dokumentasi. Instrument yang digunakan adalah dengan tes. Pengukuran menggunakan tes dilakukan sebagai alat untuk mengukur pemahaman pada materi IPS. Model tes yang digunakan adalah tes uraian karena model tes uraian mempunyai daya kreatif yang tinggi sehingga dapat untuk mengukur kemampuan pemahaman siswa. Validasi dengan cara triangulasi dan expert opinion dan teknik analisis data dengan menggunakan kualitastif dan kuantitatif.

\section{Hasil Penelitian}

\section{Proses Pembelajaran IPS dengan Menggunakan model pembelajaran Inkuiri Terbimbing}

Proses belajar mengajar yang dilaksanakan di SDN Sumber Kulon I Kecamatan Jatitujuh Kabupaten Majalengka dengan menggunakan model pembelajaran Inkuiri Terbimbing merupakan sesuatu hal yang baru dilakukan oleh siswa kelas V. Kegiatan belajar mengajar yang biasa dilakukan di SDN Sumber Kulon I masih berupa pembelajaran konvensional dimana pembelajaran bersifat teacher center.

Pelaksanaan pembelajaran dengan menggunakan model pembelajaran Inkuiri Terbimbing secara keseluruhan sudah berjalan dengan baik. Berdasarkan hasil pengamatan yang dilakukan oleh observer, pelaksanaan pembelajaran mengalami perubahan ke arah yang lebih baik meskipun dalam pelaksanaan siklus I mengalami beberapa hambatan. Sebagai seorang pengajar, maka perlu adanya Rencana Pelaksanaan Pembelajaran (RPP) agar pembelajaran berlangsung sesuai 
dengan rencana yang telah ditentukan. Oleh karena itu, pada tahap perencanaan peneliti menyusun RPP dan instrumen sebagai acuan yang digunakan dalam pelaksanaan penelitian.

Pada pelaksanaan siklus I, pelaksanaan pembelajaran yang dilakukan tidak terlepas dari berbagai macam kekurangan dan kendala yang dihadapi oleh guru. Dengan adanya bantuan dari observer, dapat diperoleh berbagai temuan esensial. Temuan esensial tersebut dapat dijadikan bahan untuk dianalisis dan refleksi pada siklus I dan dapat dijadikan bahan perbaikan pada siklus berikutnya. Temuan esensial tersebut dapat dipaparkan sebagai berikut.

Pertama, siswa belum memiliki rasa percaya diri dalam menyampaikan pendapat. Permasalahan ini menyebabkan pembelajaran menjadi pasif dan komunikasi yang terjadi hanya satu arah. Kedua, pada pelaksanaan diskusi kelompok, siswa banyak yang bermain-main dan membuat kegaduhan, hal ini dapat menyebabkan pembelajaran menjadi tidak kondusif. Ketiga, guru kurang dalam mengelola kelas sehingga pembelajaran berlangsung kurang efektif dan efisien. Keempat, siswa yang memiliki kemampuan kognitif rendah perlu mendapat bimbingan khusus.

Berdasarkan uraian tersebut, maka dapat disimpulkan bahwa penggunaan model pembelajaran Inkuiri Terbimbing dalam meningkatkan pemahaman konsep siswa pada pembelajaran IPS di kelas V SDN Sumber Kulon I Kecamatan Jatitujuh Kabupaten Majalengka berjalan dengan baik dan memberikan perubahan ke arah yang lebih baik.

\section{Pemahaman Konsep Siswa dengan Menggunakan Model Pembelajaran Inkuiri Terbimbing pada Pembelajaran IPS \\ Berdasarkan data hasil tes} evaluasi dan lembar observasi aktifitas siswa, hasil yang diperoleh menunjukan bahwa pemahaman konsep siswa pada mata pelajaran IPS materi menghargai peranan tokoh pejuang dan masyarakat dalam mempersiapkan dan mempertahankan kemerdekaan Indonesia mengalami peningkatan dari sebelum dilaksanakannya tindakan. Pada kondisi awal, pemahaman siswa masih rendah, hal tersebut disebabkan karena pembelajaran masih bersifat teacher center, guru belum memberikan kesempatan kepada siswa untuk menyampaikan pendapat ketika kegiatan belajar mengajar berlangsung, siswa belum mampu memahami konsep materi yang dipelajari sehingga berpengaruh terhadap hasil belajar siswa khususnya pada mata pelajaran IPS. Oleh karena itu, peneliti mencoba memberikan solusi untuk memecahkan permasalahan tersebut. Peneliti menggunakan model Inkuiri Terbimbing dalam upaya memecahkan permasalahan tersebut.

Setelah melakukan tindakan dengan menggunakan model Inkuiri Terbimbing pada pembelajaran IPS di kelas V, pemahaman konsep siswa menunjukkan suatu perubahan ke arah yang lebih baik. Hasil evaluasi menunjukkan adanya peningkatan pada presentase ketuntasan siswa. Kegiatan belajar mengajar menjadi lebih aktif, dapat menumbuhkan rasa percaya diri kepada siswa dalam menyampaikan pendapat, siswa lebih mampu memecahkan masalah dalam kegiatan diskusi kelompok. Hal ini menunjukkan bahwa pembelajaran IPS dengan menggunakan model Inkuiri Terbimbing berpengaruh terhadap pemahaman konsep siswa khususnya 
pada materi menghargai peranan tokoh pejuang dan masyarakat dalam mempersiapkan dan mempertahankan kemerdekaan Indonesia.

\section{Presentase Nilai Hasil Pemahaman Konsep}

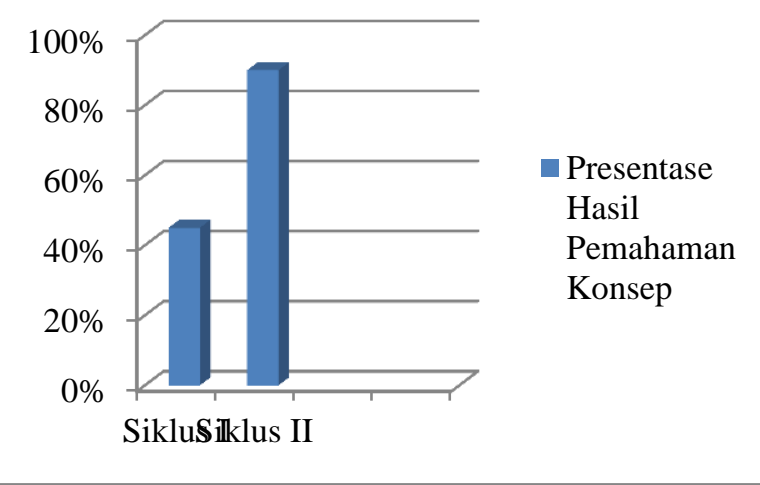

Grafik 1

Peningkatan Rekapitulasi Presentase Pemahaman Konsep

Berdasarkan grafik 4.5 pada siklus I terlihat bahwa persentase skor tes siswa mencapai $45 \%$. hal ini menunjukan bahwa siswa belum sepenuhnya mencapai ketuntasan belajar. Sedangkan pada siklus II telah mengalami penigkatan persentase tes siswa mencapai 90\%, hal ini menunjukan ada peningkatan persentase ketuntasan belajar siswa pada siklus II di sebabkan adanya peningkatan motivasi siswa dalam belajar. Peningkatan tersebut menandakan adanya peningkatan hasil belajar pada materi Menghargai jasa dan peranan tokoh perjuangan dalam mem-proklamasikan kemerdekaan Indonesia pelajaran IPS. Walaupun pada dasarnya model inkuiri terbimbing bukan satu satunya metode yang bisa di gunakan pada mata pelajaran IPS, akan tetapi pada hal ini kenyataannya dapat membantu siswa dalam memahami mata pelajaran IPS. Namun hal tersebut juga perlu didukung dengan adanya kemauan dari para siswa untuk mempelajari Ilmu Pengetahuan Sosial dengan lebih giat lagi agar motivasi siswa tentang materi yang di pelajari diharapkan dapat diaplikasikan dalam kehidupan sehari hari.

Adapun grafik peningkatan nilai rata-rata siswa dari siklus I sampai Siklus II dapat disajikan sebagai berikut:

\section{Rekapitulasi Nilai Rata- rata Siswa}

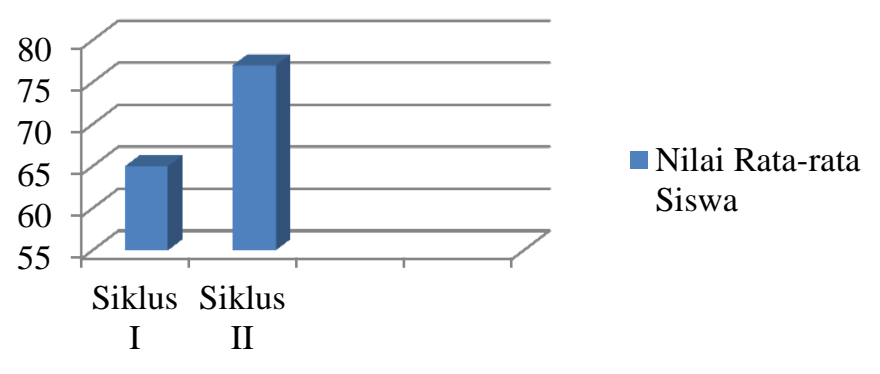

\section{Grafik 2}

Peningkatan Nilai Rata-rata Siswa

Berdasarkan grafik 4.6 nilai ratarata siswa pada kondisi awal sampai siklus II menunjukkan adanya perubahan ke arah yang lebih baik. Pada siklus I yaitu 65 sedangkan pada siklus II terlihat adanya peningkatan yaitu 77, maka target sudah tercapai karena ketuntasan disekolahnya hanya 75. Menurut Sanjaya (2008:200) pembelajaran inkuiri terbimbing yaitu suatu model pembelajaran inkuiri yang dalam pelaksanaanya guru menyediakan bimbingan atau petunjuk cukup luas kepada siswa. Sebagian perencanaannya dibuat oleh guru, siswa tidak merumuskan problem atau masalah. Dalam pembelajaran inkuiri terbimbing guru tidak melepas begitu saja kegiatan-kegiatan yang dilakukan oleh siswa. Keberhasilan menggunakan model Inkuiri Terbimbing dalam setiap tindakan penelitian, dilaksanakan oleh peneliti dengan menggunakan media gambar untuk membantu siswa dalam memahami konsep IPS. Keberhasilan penggunaan model Inkuiri Terbimbing terlihat dari hasil evaluasi siswa pada 
setiap tindakan yang relatif meningkat pada setiap siklusnya. Selain karena penggunaan model pembelajaran, pelaksanaan pembelajaran IPS di kelas $\mathrm{V}$ juga ditunjang dengan adanya media pembelajaran, keterampilan dalam mengelola kelas, memberikan arahan dan bimbingan kepada siswa, adanya penataan tempat duduk, mengajak siswa untuk mampu menyampaikan pendapat.

Penggunaan media pembelajaran dapat meningkatkan perhatian siswa. Hal ini sesuai dengan teori menurut Munadi (2013: 43) bahwa "media pembelajaran berfungsi untuk meningkatkan perhatian siswa terhadap materi ajar". Keterampilan guru dalam mengelola kelas juga berpengaruh dalam keberhasilan pembelajaran dengan menggunakan model Inkuiri Terbimbing. Hal ini sesuai dengan teori yang disampaikan oleh Arikunto (Rusdiana, 2015: 167) bahwa 'tujuan pengelolaan kelas adalah agar setiap anak di kelas dapat belajar dengan tertib sehingga tercapai tujuan pengajaran secara efektif dan efisien'. Oleh karena itu maka guru perlu memiliki keterampilan dalam mengelola kelas agar tujuan pembelajaran dapat tercapai dengan baik.

Berdasarkan pendapat Rusdiana dan Heryati (2015: 178) bahwa "guru juga perlu menata bangku dalam kelas seperti formasi meja konferensi untuk melaksanakan diskusi kelompok". Hal ini dilakukan dengan merubah anggota kelompok pada pelaksaan siklus II. Oleh karena itu, perlu dilakukan perubahan tempat duduk dengan mengganti formasi anggota kelompok. Guru perlu memberikan bimbingan dan arahan kepada siswa agar pembelajaran dapat berlangsung secara optimal.

Berdasarkan uraian di atas, maka dapat disimpulkan bahwa dengan menggunakan model Inkuiri Terbimbing dapat meningkatkan pemahaman konsep siswa pada pembelajaran IPS. Secara keseluruhan baik nilai rata-rata siswa maupun presentase ketuntasan belajar siswa mengalami peningkatan pada setiap siklusnya. Berdasarkan hal tersebut, maka penggunaan model Inkuiri Terbimbing pada pembelajaran IPS Kelas V di SDN Sumber Kulon I Kecamatan Jatitujuh Kabupaten Majalengka dapat meningkatkan pemahaman konsep siswa.

\section{Kesimpulan}

Berdasarkan pembahasan dan hasil penelitian maka dapat disimpulkan bahwa pembelajaran Ilmu Pengetahuan Sosial (IPS) dengan menggunakan model inkuiri terbimbing pada siswa kelas V dirasa dapat meningkatkan proses pembelajaran. Dimana dapat dilihat dari peningkatan terhadap aktivitas siswa selama mengikuti proses pembelajaran IPS pada siklus pertama terdapat 4 siswa berkategori rendah aktivitasnya (18\%), 15 siswa aktivitasnya kategori sedang (68\%) dan 3 siswa berkategori aktivitas tinggi (13\%). Siklus kedua 2 siswa aktivitas rendah (9\%), 5 siswa aktivitasnya sedang (22\%), dan 15 siswa aktivitasnya tinggi $(68 \%)$.

Pelaksanaan pembelajaran
dengan menggunakan model pembelajaran Inkuiri Terbimbing secara keseluruhan sudah berjalan dengan baik. Berdasarkan hasil pengamatan yang dilakukan oleh observer, pelaksanaan pembelajaran mengalami perubahan ke arah yang lebih baik meskipun dalam pelaksanaan siklus I mengalami beberapa hambatan pemahaman konsep siswa dengan menggunakan model inkuiri terbimbing. Berdasarkan data yang diperoleh dari hasil penelitian tindakan kelas yang telah dilaksanakan dalam dua siklus pada upaya meningkatkan pemahaman konsep Ilmu Pengetahuan Sosial (IPS) melalui model inkuiri terbimbing pada siswa kelas V SDN Sumber Kulon I Tahun Pelajaran 2016/2017, dapat disimpulkan bahwa terjadi peningkatan 
pemahaman konsep IPS pada siswa kelas V SD Negeri Sumber Kulon I, setelah dilaksanakannya pembelajaran dengan menggunakan model inkuiri terbimbing.

Hal tersebut terlihat pada peningkatan rata-rata kelas serta jumlah siswa yang mencapai ketuntasan belajar pada setiap siklusnya, yaitu rata-rata pada siklus I 65 dan meningkat menjadi 77 pada siklus II. Peningkatan ketuntasan belajar IPS siswa adalah pada siklus I hanya ada 10 siswa yang tuntas belajar dengan persentase $45 \%$, sedangkan siswa yang belum tuntas belajar sebanyak 12 siswa dengan presentase $54 \%$ meningkat pada siklus II menjadi 20 siswa tuntas belajar dengan persentase $90 \%$ dengan siswa yang tidak tuntas belajar sebanyak 2 siswa dengan persentase $9 \%$.

\section{Daftar Pustaka}

Anam Khoirul .(2016). Pembelajaran Berbasis Inkuiri Metode Dan Aplikasi. Yogyakarta: Pustaka Pelajar.

Arifin Zaenal. (2009). Evaluasi Pembelajaran . Bandung : PT REMAJAROSDAKARYA

Gumay, Thia Dwi Susanti Putri. (2014). Penerapan motode inkuiri untuk meningkatkan hasil belajar fisika siswa kelas VIII.6 pada konsep bunyi di Smp Negeri 3 Kota Bengkulu. UNIB Scholar Repository.

Irwandani. (2015). Pengaruh Model Pembelajaran Generatif Terhadap Pemahaman Konsep Fisika Pokok Bahasan Bunyi Peserta Didik Mts AlHikmah Bandar Lampung. Jurnal Ilmiah Pendidikan Fisika A1Biruni Vol 4 No 2 (2015). https://doi.org/10.24042/jpifalbiruni.v4i2.90

Mulyana, Eldi. (2014). Jurnal Model Pembelajaran Generatif Sebagai Upaya Meningkatkan Pemahaman Konsep Ips Pada Peserta Didik. Jurnal Pendidikan Ilmu Sosial
UPI Vol 23 No 2 (2014). Hal 2633.

Munadi, Yudhi. (2013). media pembelajaran. Jakarta:referensi.

Kunandar. (2009). Penelitian tindakan kelas. Jakarta: rajawali press.

Rusdiana A \& Heryati, Yeti. (2015). Pendidikan Profesi Keguruan. Bandung:Pustaka Setia.

Sanjaya, Wina. (2006) "Strategi Pembelajaran Berorientasi Standar Proses Pendidikan". Bandung: Kencana.

Sanjaya, Wina (2009) Strategi Pembelajaran Berorientasi Standar Proses. Jakarta: Pendidikan. Prenada.

Sanjaya, Wina (2006). Strategi Pembelajaran. Jakarta: PRENADA MEDIA GROUP

Sapriya. (2009). Pendidikan IPS. Bandung : PT Remaja Rosdakarya

Susanto, Ahmad. (2016). Teori Belajar Dan Pembelajaran Disekolah Dasar. Jakarta: Prenadamedia Group.

Rahayu, Widi K (2014). Peningkatan Prestasi Belajar Ips Melalui Penerapan Metode Inkuiri Terbimbing Pada Siswa Kelas V Sd Negeri Umbulwidodo Ngemplak Sleman.

Waluya, Bagja. (2014).Jurnal penggunaan model pembelajaran generatif untuk meningkatkan pemahaman siswa pada konsep geografi. 